\title{
Establishment and Performance of Cactus (Opuntia ficus-indica) Accessions at Initial Stages under Shed Net in Semi-Arid Region of Rajasthan
}

\author{
V. Khandelwal ${ }^{1,3^{*}}$, M.B. Noor Mohamed ${ }^{1}$, A.K. Shukla ${ }^{1}$, \\ Shamsudheen Mangalassery ${ }^{2}$ and Devi Dayal ${ }^{2}$
}

${ }^{1}$ ICAR-Central Arid Zone Research Institute, Regional Research Station, Pali-Marwar, Rajasthan-306 401 (India)

${ }^{2}$ ICAR-Central Arid Zone Research Institute, Regional Research Station, Kukma-Bhuj, Gujarat-370 105, (India)

${ }^{3}$ ICAR-AICRP on Pearl Millet, ARS, AU, Mandor, Jodhpur, Rajasthan- 342 304, (India)

*Corresponding author

\begin{tabular}{|l|}
\hline Ke y w o r d s \\
Cactus, Accessions, \\
$\begin{array}{l}\text { Survival rate, Semi- } \\
\text { Arid region }\end{array}$ \\
\hline Article Info \\
\hline $\begin{array}{l}\text { Accepted: } \\
\text { 15 September } 2019 \\
\text { Available Online: } \\
10 \text { October } 2019\end{array}$ \\
\hline
\end{tabular}

\section{Introduction}

Opuntiaficus-indica (Cactus), commonly known as prickly pear and belongs to the order Caryophyllales and the family Cactaceae. Locally cactus is called nagphani or dandathohar. Chapathikalliis the common name of plant used in Tamil Nadu. It is reported to contain about 130 genera and nearly 1500 species, which is a new crop in India although its spiny type, bearing very small fruits (locally called nagphani) and it is found wild in arid and semiarid plateau regions. Owing to its xerophytic 
characteristics and capability for greater conversion of water to dry matter than by either $\mathrm{C}_{3}$ or $\mathrm{C}_{4}$ plants through a specialized photosynthetic mechanism called Crassulacean acid metabolism (Felker et al., 1997; Mizrahi et al., 1997), it was considered as a potential crop species for the water-scarce arid parts of India.

It has a marked capacity to withstand prolonged drought (Nobel, 1995; Felker et al., 1997), extreme heat (Sudzuki, 1995), highly efficient in water use (Nobel, 1995; Snyman, 2004; Snyman, 2005), moderately tolerant to salinity (Gajendra et al., 2014) and are considered as an important potential source of food and fodder (Mishra et al., 2006; Mathur et al., 2009) in many desert areas of the world. It is considered as a natural reservoir of water and may reduce the water requirement of cattle (Flores-Hernández et al., 2004). Many species of cactus are found growing as wild plants in arid (less than $250 \mathrm{~mm}$ annual precipitation) and semi-arid (250-450 $\mathrm{mm}$ annual precipitation) regions of India. In addition to its remarkable value as cattle and human food, it can act as biological barrier to prevent and control top-soil loss (Nefzaoui and El Mourid, 2009) and increase fodder availability for animals (Alary et al., 2007). Opuntias are also important as cover in arid and semi-arid areas because they can survive and spread under conditions of scarce and erratic rainfall and high temperatures and can play an important role in the protection of local fauna.

Also, cactus pear has multiple uses. It produces sweet, nutritionally rich edible fruits, its tender cladodes are used as fresh green vegetable and salad, mature cladodes or cactus stems are used as nutritive fodder for milch animals (Vishal Nath et al., 1999). The fruit, as well as cactus stem are used to prepare value-added products, such as jam, squash, wine, pickle, body lotions, shampoo, creams, etc. It also has several medicinal and industrial uses (Singh and Felker, 1998). The fruit is a fleshy berry, varying in shape, size, and colour and has a consistent number of hard seeds. The fairly high sugar content and low acidity of the fruit make it very sweet and delicious. Cacti, and specifically Opuntia spp., have been extremely useful livestock forage in times of drought, primarily by providing digestible energy, water and vitamins. Although mainly used for cattle, opuntia has also been used as forage for pigs.

Owing to this importance, it may be considered as a potential crop species for the water-scarce arid parts of India. In recent years, an attention of growing spineless cactus pear in the drier areas of India in terms of fruit, fodder and vegetable production is increasing (Singh and Singh, 2003; Pareek et al., 2003; Singh, 2006). Therefore, present investigation has been carried out to estimate survival rate and initial establishment of cactus populations (before and after rainfall) which is collected from different region of arid zone of India under semi-arid condition of Rajasthan.

\section{Materials and Methods}

The study was conducted on fifteen accessions of cactus in shade net house condition in Central Arid Zone Research Institute (CAZRI), Regional Research Station, PaliMarwar, Rajasthan situated at $25^{\circ} 46^{\prime} \mathrm{N}$ longitude and $73^{\circ} 50^{\prime} \mathrm{E}$ latitude at $225 \mathrm{msl}$ during the year 2016. The soil is fine sandy clay loam with high silica content in texture and alkaline with $\mathrm{pH}$ 8.5. Fifteen accessions of cactus were collected from different region of arid zones of India and efforts were made to multiply these accessions in pots. The planting materials were consisted of two cladodes or two pieces of a cladode from each clone and it was weighed prior to planting ( $200 \mathrm{~g}$ to 400 g). The cladodes were dried under partial 
shade and treated with Bavistin (0.2\%). Planting was done in cement pots which were filled with a mixture of farmyard manure and soil in the month of March. The planting was done at the depth of $5 \mathrm{~cm}$ (1/3rd portion of cladode) in pots as suggested by Pareek et al., (2002). Survival rate and growth of cladodes were measured before (March to May, 2016) and after rain fall (July to August, 2016). Survival Percentage (\%) (before and after rainfall), number of cladodes, days to sprouting were measured and observations were recorded.

\section{Results and Discussion}

\section{Survival percentage (\%) before and after rainfall}

Differences among the accessions were observed in survival rate of cladodes before and after rainfall (Table 1). The survival rate of cladodes before rainfall ranged between $100 \%$ and $40 \%$. The highest survival percentage of cladodes before rainfall was recorded in Trunzara Red San Cono, ARL Spineless, Roso Castle Sardo and Algerian (100\%). The accessions from 1271 (40\%) and Bianca Macromer (40\%) followed by Piantra$25(67 \%)$ and Trunzara Red Bronte $(67 \%)$ had lowest survival percentage before rainfall. But after rainfall the survival percentage was decreased and it ranged from $80 \%$ to $31.4 \%$. The highest survival rate of the cladodes was observed in ARL Spineless (80\%), Roso San Cono (80\%) and Algerian (80\%) whereas lowest was 1271(31.4\%) followed by Bianca Macromer (37) and 1308 (50\%) after rainfall (Table 1).

Survival rate before rain (March to June-2016) is better as compare to after commencement of rain (from July-2016). Because of heavy rainfall the rotting of cladodes is more. It may be due to water logging condition in pots. The infestation of fungus Phytophthora nicotiana may be more because of favorable climatic condition. Nallathambi et al., (2005) also reported that foot rot caused by Phytophthora nicotianae has been observed as a major disease in the establishment of cactus pear (Opunita spp.) under arid conditions. Foot rot incidence was prevalent in $23.5 \%$ of the germplasm collections during the months of August and November. Guvera (2001) suggested that the cactus and other droughttolerant and water-efficient fodder shrubs are better growing in deep sandy soils under low rainfall condition (100-150 mm). Gajendra et al., (2014) also reported that cactus has lower tolerance to salinity at establishment and survival stage.

\section{Growth parameters of cactus accessions}

Days to sprouting was higher in Piantra-25 (72 days) followed by Roso Castle Sardo (70 days), ARL Spineless and Algerian (69 days) lower in Trunzara Red San Cono (28 days) followed by Bianca Macromer (30 days). Seven accessions sprouted in 28 to 49 days and others sprouted after over 50 days (Table 1). Under the semiarid conditions of Karnal (India), the cladodes sprouted after 57 to 100 days after planting (Singh and Felker, 1998). But, earlier sprouting was occurred at RRS, Pali-Marwar seems to be related to the warmer conditions during the month of March. Number of cladodes per plants ranged between 6 and 2. Maximum number of cladodes per plant was observed in 1270 and 1308 (6) followed by Trunzara Red San Cono (5) whereas minimum was in White San Cono (2).Singh (2003) and Soni et al., (2015) also reported higher number of cladodes in accessions 1270 and 1271. Maximum plant height was recorded in $1308(71.8 \mathrm{~cm})$ followed by $1271(64.0 \mathrm{~cm})$ and Trunzara Red San Cono $(59.0 \mathrm{~cm})$ whereas minimum was Bianca Macromer $(20.5 \mathrm{~cm})$ (Table 2). The cladodes length of plant varied in different accessions. 
Table.1 Survival percentage and days for sprouting of different cactus accessions

\begin{tabular}{|l|l|c|c|c|c|}
\hline S.No. & \multicolumn{1}{|c|}{ Cactus Accessions } & $\begin{array}{c}\text { Survival } \\
\text { Percentage } \\
(\boldsymbol{\%}) \\
\text { (Before } \\
\text { Rain) }\end{array}$ & $\begin{array}{c}\text { Survival } \\
\text { Percentage } \\
(\boldsymbol{\%}) \mathbf{( A f t e r} \\
\text { Rain) }\end{array}$ & $\begin{array}{c}\text { Days for } \\
\text { sprouting }\end{array}$ & $\begin{array}{c}\text { Number of } \\
\text { cladodes } \\
\text { per plant }\end{array}$ \\
\hline $\mathbf{1 .}$ & 1270 & 80 & 60 & 45 & 6 \\
\hline $\mathbf{2 .}$ & 1271 & 40 & 31.4 & 45 & 3 \\
\hline $\mathbf{3 .}$ & CAZRI BOT Garden & 80 & 55 & 46 & 3 \\
\hline $\mathbf{4 .}$ & 1308 & 80 & 50 & 66 & 6 \\
\hline $\mathbf{5 .}$ & Bianca Macromer & 40 & 37 & 30 & 3 \\
\hline $\mathbf{6 .}$ & Trunzara Red San Cono & 100 & 60 & 28 & 5 \\
\hline $\mathbf{7 .}$ & Piantra-25 & 67 & 55 & 72 & 3 \\
\hline $\mathbf{8 .}$ & ARL Spineless & 100 & 80 & 69 & 3 \\
\hline $\mathbf{9 .}$ & Red San Cono & 85.8 & 57.1 & 50 & 4 \\
\hline $\mathbf{1 0 .}$ & Roso Castle Sardo & 100 & 75 & 70 & 4 \\
\hline $\mathbf{1 1 .}$ & Roso San Cono & 80 & 80 & 48 & 3 \\
\hline $\mathbf{1 2 .}$ & Algerian & 100 & 80 & 69 & 3 \\
\hline $\mathbf{1 3 .}$ & Trunzara Red Bronte & 67 & 55 & 66 & 3 \\
\hline $\mathbf{1 4 .}$ & Yellow Rocca Palumba & 80 & 66 & 66 & 3 \\
\hline $\mathbf{1 5 .}$ & White San Cono & 80 & 66 & 49 & 2 \\
\hline & & & & & \\
\hline
\end{tabular}

Table.2 Growth parameters of different cactus accessions

\begin{tabular}{|l|l|c|c|c|c|c|}
\hline S.No. & \multicolumn{1}{|c|}{ Cactus Accessions } & $\begin{array}{c}\text { Number of } \\
\text { cladodes } \\
\text { per plant }\end{array}$ & $\begin{array}{c}\text { Plant } \\
\text { Height } \\
\text { (cm) }\end{array}$ & $\begin{array}{c}\text { Cladode } \\
\text { Length } \\
\text { (cm) }\end{array}$ & $\begin{array}{c}\text { Cladode } \\
\text { Width } \\
\text { (cm) }\end{array}$ & $\begin{array}{c}\text { Cladode } \\
\text { Thickness } \\
\text { (cm) }\end{array}$ \\
\hline 1. & 1270 & 6 & 39.5 & 22.20 & 17.0 & 1.32 \\
\hline 2. & 1271 & 3 & 64.0 & 22.80 & 6.25 & 0.65 \\
\hline 3. & CAZRI BOT Garden & 3 & 39.5 & 25.60 & 8.85 & 0.90 \\
\hline 4. & 1308 & 6 & 71.8 & 19.06 & 4.03 & 0.90 \\
\hline $\mathbf{5 .}$ & Bianca Macromer & 3 & 20.5 & 17.50 & 5.20 & 0.50 \\
\hline 6. & Trunzara Red San Cono & 5 & 59.0 & 18.70 & 6.76 & 0.56 \\
\hline 7. & Piantra-25 & 3 & 54.5 & 26.00 & 7.36 & 0.86 \\
\hline 8. & ARL Spineless & 3 & 40.0 & 20.20 & 6.13 & 0.60 \\
\hline 9. & Red San Cono & 4 & 46.0 & 18.40 & 5.10 & 0.40 \\
\hline $\mathbf{1 0 .}$ & Roso Castle Sardo & 4 & 36.0 & 13.25 & 6.65 & 0.40 \\
\hline 11. & Roso San Cono & 3 & 53.3 & 23.15 & 4.85 & 0.55 \\
\hline 12. & Algerian & 3 & 51.0 & 13.00 & 4.63 & 0.63 \\
\hline 13. & Trunzara Red Bronte & 3 & 51.0 & 20.00 & 6.25 & 0.65 \\
\hline 14. & Yellow Rocca Palumba & 3 & 31.0 & 20.25 & 5.40 & 0.55 \\
\hline 15. & White San Cono & 2 & 47.0 & 16.50 & 4.70 & 0.50 \\
\hline
\end{tabular}


The accession Piantra-25 recorded the maximum $(26.0 \mathrm{~cm})$ length followed by the accession CAZRI BOT Garden $(25.60 \mathrm{~cm})$. The Length of cladodes was minimum in accession Algerian $(13.0 \mathrm{~cm})$ followed by Roso Castle Sardo (13.25 cm) (Table 2). Maximum width of cladode $(17.0 \mathrm{~cm})$ was attained by the accession 1270 followed by CAZRI BOT Garden $(8.85 \mathrm{~cm})$. Minimum cladode width $(4.03 \mathrm{~cm})$ was recorded in accession 1308 (Table 2). Regarding cladodes thickness, it was observed that the accession 1270, CAZRI BOT Garden and 1270 had the largest cladode thickness of $1.32 \mathrm{~cm}, 0.90 \mathrm{~cm}$ and $0.90 \mathrm{~cm}$., respectively (Table 2 ). The lowest cladode thickness $(4.9 \mathrm{~cm})$ was observed in the accession Red San Cono (0.40 $\mathrm{cm})$ followed by Roso Castle Sardo (0.40 $\mathrm{cm})$. Such variation in size of cladodes has also been reported from Phaltan in southern India (Anon., 1993), CAZRI, RRS, Bikaner (Soniet al., 2015) and Agra in central India (Singh, 2000).

\section{References}

Alary, V., Nefzaoui, A. and Ben Jemaa, M. 2007. Promoting the adoption of natural resource management technology in arid and semi-arid areas: modeling the impact of spineless cactus in alley cropping in Central Tunisia. Agroforestry Systems. 94: 573-585.

Anonymous. 1993. Genetic selection and improvement of Opuntia cultivars for human and animal food on semi-arid lands. Final Project Report, Nimbkar Agricultural Research Institute, Phaltan (Maharashtra), India. p. 89.

Felker, P., Gurbachan Singh and Pareek, O. P. 1997. Opportunities for development of Cactus (Opuntia spp.) in arid and semiarid regions. Annals of AridZone.36: 267-278.

Flores-Hernández, A., Orona-Castillo, I., Murillo-Amador, B., Garcia-Hernandez,
J. L. and Troyo-Dieguez, E. 2004. Yield and physiological traits of prickly pear cactus 'nopal' (Opuntia spp.) cultivars under drip irrigation. Agricultural WaterManagement.70: 97-107.

Gajendra, G., Gurbachan Singh, Dagar, J. C., Khajanchi Lal and Yadav, R. K. 2014. Performance of edible cactus (Opuntia ficus-indica) in saline environments. Indian Journal of Agricultural Sciences.84: 509-513.

Mathur, B. K., Patil, N. V., Mathur, A. C., Meghwal, P. R., and Bohra, R.C. 2009. Effect of feeding rich resource thornless cactus (Opuntia ficus-indica) to Tharparkar cattle in arid region. In: Proc. International Conference on Nurturing Arid Zones for People and the Environment: Issue and Agenda for the $21^{\text {st }}$ Century (November 24-28, 2009), Central Arid Zone Research Institute, Jodhpur, p.271.

Mishra, A. K., Mishra, A. S., Tripathi, M. K., Chaturvedi, O. H., Vaithiyanathan, Prasad, R. and Jakhmola, R.C.2006. Intake, digestion and microbial protein synthesis in sheep on hay supplemented with prickly pear cactus [Opuntiaficusindica(L.) Mill.]with or without groundnut meal. Small RuminantResearch.63: 125-134.

Nallathambi, P., Umamaheshwari, C. and Singh, R.S. 2005.Foot rot (Phytophthora nicotianae) in cactus pear (Opuntia spp.) genotypes under arid conditions. Annals of Arid Zone. 44 (1): 59-63.

Mizrahi, Y., Nerd, A., and Nobel, P.S. 1997. Cacti as crops. Horticultural Review. 18: 291-346.

Nefzaoui, A. and El Mourid, M. 2009. Cacti: A key-stonecrop for the development of marginal lands and to combat desertification. In: F.A.P. Campos, J.C.B. Dubeux Jr. and S. de Melo Silva (eds.) Proc. Sixth International 
Congress on Cactus Pear and Cochineal. Acta Horticulture.11: 365374.

Nobel, P.S. 1995. Environmental biology. In: G. Barbera, P. Inglese and E. PimientaBarrios (eds.) Agroecology, Cultivation and Uses of Cactus Pear. FAO Plant Production and Protection Paper 132. FAO, Rome. pp. 213.

Pareek, O.P., Singh, R.S. and Vashishtha. B.B. 2003. Performance of cactus pear [Opuntiaficus-indica(L.) Mill.] clones in hot arid region of India. Journal of Professional Association of Cactus Development.5: 121-130.

Singh, R.S. 2000. Studies on propagation and growth behaviour in cactus pear (Opuntiaficus-indica(L.) Mill.) as affected by size and age of cladode, season and methods of planting and growth regulators. Ph.D. thesis, Dr. B.R. Ambedkar University, Agra, India.

Singh, Gurbachan. 2006. An overview of cactus pear research and development in India. Acta Horticulture (ISHS). 728: 43-50.

Singh, G.B. and Felker, P. 1998. Cacti: a new world food. Indian Horticulture. 43:2629.

Singh, R. S. and Singh, V. 2003. Growth and development influenced by size, age, and planting methods of cladodes in cactus pear (Opuntiaficus-indica(L.) Mill.). Journal of Professional Association of Cactus Development.5: 47-54.

Soni, M. L., Yadava, N. D., Suresh Kumar and Roy, M. M. 2015. Evaluation for growth and yield performance of prickly pear cactus (Opuntiaficus-indica (L.) Mill) accessions in hot arid region of Bikaner, India. Range Mgmt. \& Agroforestry.36 (1): 19-25

Snyman, H. A., 2004. Effect of various water applications on root development of Opuntiaficus-indica and O.robusta under greenhouse growth conditions. Journal of Professional Association of CactusDevelopment.6: 35-61.

Snyman, H. A., 2005. A case study on in situ rooting profiles and water-use efficiency of cactus pears, Opuntiaficusindica and $O$. robusta. Journal of Professional Association of Cactus Development.7: 1-21.

Vishal Nath, Singh. R.S., Shukla, A.K. and Vashishtha. 1999. Cactus pear (Opuntiaficus indica Mill.) as an emerging fruit crop for arid and semiarid regions of India. Curr. Agric. 23(12): 49-58.

\section{How to cite this article:}

Khandelwal, V., M.B. Noor Mohamed, A.K. Shukla, Shamsudheen Mangalassery and Devi Dayal. 2019. Establishment and Performance of Cactus (Opuntia ficus-indica) Accessions at Initial Stages under Shed Net in Semi-Arid Region of Rajasthan. Int.J.Curr.Microbiol.App.Sci. 8(10): 1983-1988. doi: https://doi.org/10.20546/ijcmas.2019.810.231 